\title{
Monitoring of Ultrafine Particles in the Surrounding Urban Area of In-Land Passenger Ferries
}

\author{
Margarida Lopes $^{1^{*}}{ }^{(0)}$, Ana Russo ${ }^{2}$, Célia Gouveia ${ }^{2,3}$, Francisco Ferreira $^{4}$ \\ ${ }^{1}$ Department of Sciences and Environmental Engineering, NOVA School of Science and Technology, NOVA University of Lisbon, \\ Caparica, Portugal \\ ${ }^{2}$ Instituto Dom Luiz (IDL), Faculdade de Ciências da Universidade de Lisboa, Lisboa, Portugal \\ ${ }^{3}$ Portuguese Institute for Sea and Atmosphere, Lisbon, Portugal \\ ${ }^{4}$ Centre for Environmental and Sustainability Research (CENSE), NOVA School of Science and Technology, NOVA University of \\ Lisbon, Caparica, Portugal \\ Email: *mm.lopes@campus.fct.unl.pt
}

How to cite this paper: Lopes, M., Russo, A., Gouveia, C. and Ferreira, F. (2019) Monitoring of Ultrafine Particles in the Surrounding Urban Area of In-Land Passenger Ferries. Journal of Environmental Protection, 10, 838-860.

https://doi.org/10.4236/jep.2019.106050

Received: May 1, 2019

Accepted: June 21, 2019

Published: June 24, 2019

Copyright $\odot 2019$ by author(s) and Scientific Research Publishing Inc. This work is licensed under the Creative Commons Attribution International License (CC BY 4.0).

http://creativecommons.org/licenses/by/4.0/

\begin{abstract}
Maritime transportation, widely used both in international transport of goods and touristic purposes, has been identified as a significant source of ultrafine particles (UFP). In-land passenger ferry is a source of UFP far less addressed; however, in locations with relatively high frequency of this transportation mode, it is expected that they contribute to an increase of their concentration. Moreover, the negative effects of UFP on human health and environment are known and therefore, monitoring UFP produced by ferries is vital to assess the degree of exposure of who work or live close to ferries' terminals or downwind to their cruising path. This work aims to study the influence of in-land ferries activities on UFP in the urban/suburban areas near ferries' terminals and downwind across the cruising path. The UFP monitoring campaign was carried out from September to December 2018 for 19 non-consecutive periods. The sampling sites were chosen in order to maximize measurements under downwind conditions and allow the association between ferry operation and UFP concentration response. Based on data collected, correlation analysis was performed between ferry's traffic and particle number counting (PNC) of UFP, and also with meteorological variables. Results show an increase in PNC ranging from 25 to 197\% during the third minute around a ferry movement and are moderate to positive significant correlations between PNC values and the number of ferry operations $(r=0.79$ to $r=0.94)$, showing that UFP emitted by in-land ferries contributes to PNC increase. Moreover, negative correlations $(r=-0.85$ to $r=-0.93)$ between PNC and wind intensity were also found.
\end{abstract}




\section{Keywords}

Air Pollution, PNC, In-Land Passenger Ferries, Monitoring Campaign, Health

\section{Introduction}

Maritime transportation (MT) is widely used for passenger carriage, for touristic purposes and for international or intercontinental transport of goods. According to the United Nations Conference on Trade and Development, more than $80 \%$ of world trade is carried by sea [1]. During the past decades MT registered a significant global increase which is expected to continue over the coming decades [2] [3], leading to the increase of research on its environmental impacts (e.g. [4] [5] [6] [7] [8]. Shipping emerged as an important source of air pollution in coastal areas [5] mainly associated with the large quantities of particulate matter (PM) emitted and the consequent implications on air quality and human health.

While the impacts on health of $\mathrm{PM}_{10}$ and $\mathrm{PM}_{2.5}$ are well scientifically recognized, studies on UFP health impacts are scarce [9]. The UFP ingress into the human body is mainly processed by respiratory, dermal and ingestion ways [10]. Once they enter the human body, due to their small size, they rapidly reach the bloodstream and spread through all organs [11]. Because of their small size, UFP can be associated with increased reactivity and toxicity [12] [13], being also capable of crossing the cell membranes and damage intracellular proteins, organelles and DNA [14] [15] [16] [17] [18].

Knowledge on UFP health effects is limited because they are not usually measured [19]. According to this study, a positive correlation, even though not statistically significant, has been observed between prolonged exposure to UFP and mortality due to breathing problems. However, the few epidemiological studies carried out on the effect of UFP on the mortality rate have revealed inconsistent results, and the authors claim that more years of studies are needed to draw more precise conclusions [19]. On the other hand, results from several studies advise that prolonged exposure to high concentrations of UFP may be responsible for reduced lung function and/or aggravation of respiratory diseases, such as asthma or chronic obstructive pulmonary disease [18] [20] [21] [22] [23].

Although clinical studies related to UFP exposure are still not enough for unequivocal conclusions regarding their toxicity, they highlight that their effects should not be neglected [24]. Respiratory and cardiopulmonary problems, increased hospitalization [25], and mortality rates, especially due to lung cancer, are already associated with exposure to particulate matter $\left(\mathrm{PM}_{10}\right.$ and $\left.\mathrm{PM}_{2.5}\right)$ [11] [26] [27]. Back in 2013, the International Cancer Research Agency, classified diesel engines exhaust particulate matter, as a Group I carcinogen [28]. Exposure to $\mathrm{PM}_{10-2.5}$ during gestation, regardless gestational stage, was associated with be- 
low-average birth weight infants [29]. The economic costs associated with these health effects could be considerably reduced by decreasing the atmospheric concentration of particulate matter [30] [31].

Recent results indicated that $30 \%$ to $40 \%$ of the particulate matter from shipping is emitted as a primary source and $60 \%$ to $70 \%$ as secondary [4]. Shipping PM consists mainly on fine to ultrafine fraction (e.g. elementary or black carbon $(\mathrm{BC})$, nickel $(\mathrm{Ni})$, vanadium $(\mathrm{V})$, etc.) or results from chemical reactions between exhaust gases and particles in the atmosphere [32]. Besides PM, shipping also emits gaseous pollutants, such as nitrogen oxides $\left(\mathrm{NO}_{\mathrm{x}}\right)$, sulphur dioxide $\left(\mathrm{SO}_{2}\right)$ and smaller amounts of carbon monoxide $(\mathrm{CO})$ and volatile organic compounds (VOCs). Maritime traffic is also a relevant source of greenhouse gases (GHG), namely carbon dioxide $\left(\mathrm{CO}_{2}\right)$ and small amounts of nitrous oxide $\left(\mathrm{N}_{2} \mathrm{O}\right)$ and methane $\left(\mathrm{CH}_{4}\right)$ [7]. Beyond health consequences, $\mathrm{PM}$ emissions are climate forcing agents [6] [8] [33] [34]. They affect mainly the radiative balance and cloud formation, since they act as water condensation nuclei [35] [36]. Ice and clouds albe do are also affected, although the uncertainty of the global effect is still high.

Maritime traffic's impacts should also be evaluated in the context of harbour locations (e.g. close to urban and suburban areas), as air quality in the surroundings is particularly affected with consequences to human health for populations living in coastal urban areas [4]. It is estimated that $70 \%$ of ship's emissions occur close to the coast, within $400 \mathrm{~km}$ from land [37] and disperse directly onto mainland, which worsens the environmental impacts associated with maritime traffic (e.g. local air quality) affecting both human health and ecosystems [38] [39]. Research suggests that, in certain cases, ships in harbour may contribute to about $55 \%$ to $77 \%$ of total emissions within their vicinity [40] [41]. Regarding European coastal areas, shipping emissions contribute to $1.7 \%$ of $\mathrm{PM}_{10}$ (PM with aerodynamic diameter less than $10 \mu \mathrm{m}$ ) air concentrations, $1.14 \%$ of $\mathrm{PM}_{2.5}$ (aerodynamic diameter less than $2.5 \mu \mathrm{m}$ ) concentrations and at least $11 \%$ of $\mathrm{PM}_{1}$ (aerodynamic diameter less than $1 \mu \mathrm{m}$ ) concentrations [4]. In the western Mediterranean region, the Barcelona's harbour contributes to $31 \%$ of $\mathrm{PM}_{10}$ average mass [42]. A more recent study carried out by [43] suggests that in the harbour, ship emissions are responsible for $9 \%-12 \%$ of $\mathrm{PM}_{10}$ and $11 \%$ $15 \%$ of $\mathrm{PM}_{2.5}$ concentrations in the Barcelona urban area. Other studies identified lower values for $\mathrm{PM}_{2.5}$, namely in the harbour industrial area of Brindisi (Italy) where the primary in-harbour shipping emissions of $\mathrm{PM}_{2.5}$ are $\sim 3 \%$ while the average ship traffic related is reported to be $~ 7 \%$ [44] [45]. More recently, a study focused in Oslo's harbour estimates oceangoing vessels as the main emission source of air pollution, contributing $63 \%$ to $78 \%$ of the total $\mathrm{NO}_{x}, \mathrm{PM}_{10}, \mathrm{SO}_{2}$ and $\mathrm{CO}_{2}$ emissions [7]. The authors highlight international ferries, cruises and container vessels as the main contributors among oceangoing vessels. [46] estimated the impact of shipping in Calais harbour on average concentrations to be $51 \%$ for $\mathrm{SO}_{2}, 35 \%$ for $\mathrm{NO}, 15 \%$ for $\mathrm{NO}_{2}$ and $2 \%$ for $\mathrm{PM}_{10}$. According to the same study the in-port ships average impact on $\mathrm{PM}_{10}$ concentrations are estimated to 
be $+28.9 \mu \mathrm{g} \cdot \mathrm{m}^{-3}$, from which $40 \%$ are $\mathrm{PM}_{1}$. The authors also found that, under certain circumstances, punctually $\mathrm{PM}_{10}$ concentration can reach a concentration value close to $100 \mu \mathrm{g} \cdot \mathrm{m}^{-3}$. Furthermore, the daily limit value established in the European Directive 2008/50/EC of 21 May $2018\left(50 \mu \mathrm{g} \cdot \mathrm{m}^{-3}\right)$ was exceeded for several days.

On a wider-range, [47] summarized the results of several studies concerning ship-related emissions inventories for different worldwide countries. Considering $\mathrm{PM}_{10}$ emissions in European countries, the authors accounted emissions ranging from 10 to $1500 \mathrm{t}$ /year. This report also highlights Portugal's emissions as the highest, quoting a study conducted on four Portuguese harbours [48].

$\mathrm{PM}$ in its different typologies $\left(\mathrm{PM}_{10}, \mathrm{PM}_{2.5}\right.$ and $\left.\mathrm{PM}_{1}\right)$ is one of the most harmful pollutants to human health [49], leading to health impacts on populations exposed to them such as people living close to harbours or in coastal urban areas, or shipyard workers [5] [7] [46] [50]. Other study [51], concluded the vast majority of freshly emitted ship exhaust particles lie in the ultrafine mode, communally designated by UFP (particles, with an aerodynamic diameter less than $0.1 \mu \mathrm{m}$ ). Apart from the above mentioned and more common reference to $\mathrm{PM}_{10}, \mathrm{PM}_{2.5}$ and $\mathrm{PM}_{1}$ emissions from ships, UFP has been also addressed in studies related to shipping emissions (e.g. [50] [52] [53] [54]). Regarding heavy fuel oil used by ships, emission factors for particle number were found in the range 5 $\times 10^{15}$ to $1 \times 10^{17} \mathrm{pt} \cdot \mathrm{kg}^{-1}$ fuel [55]. [5] found out emission factors of $2.79 \pm 0.19 \mathrm{vs}$. $2.35 \pm 0.20 \times 10^{16} \mathrm{pt} \cdot \mathrm{kg}^{-1}$ fuel for cargo and passenger ships, respectively. The influence of shipping and harbours was found to be relevant for Helsinki, Oslo, Rotterdam and Athens [50]. Two studies carried out in Santa Cruz de Tenerife City found UFP linked to ship emissions of $15-45 \times 10^{3} \mathrm{pt} \cdot \mathrm{cm}^{-3}$ [52] and $35-50$ $\times 10^{3} \mathrm{pt} \cdot \mathrm{cm}^{-3}$ when meteorological conditions allowed ship plumes inland transport by sea breezes [56]. Another study, concerning Brindisi and Venice (Italy), Patras (Greece) and Rijeca (Croatia), concluded that shipping and harbours contributions to UFP emissions have an impact 2 to 4 times larger than $\mathrm{PM}_{1-10}$ [57]. In Crete, [54] found high UFP concentrations related to aviation and shipping emissions transported from the nearby airport and harbour.

Furthermore, within urban areas, the main source of UFP is the direct emission from combustion processes; the new particle formation (NPF) is a main provider to particulate pollution, being a secondary source of UFP [58]. NPF occurs by nucleation of gas precursors and posterior growth by condensation on the formed particles is a common atmospheric process, being recurrently referred by several studies as an important process in maritime areas [59] [60] [61]. NFP events are common in coastal areas once the combined mixing of clean marine air and UFP enriches urban air and leads to appropriate conditions for particle formation [62]. Therefore, UFP concentration can significantly be increased in coastal urban areas [63] [64]. Additionally, NPF events have been studied regarding to meteorological variables (temperature, relative humidity, solar radiation, wind speed and direction) to identify the conditions that improve particle nucleation. Although the impact of temperature is still ambigu- 
ous, several authors point that NPF is enabled by higher solar radiation [58], moderate relative humidity [65] [66] and, considering coastal areas, it is likely to take place during sea breeze [62] [67].

Although there are many studies evaluating the effects on shipping-related course and fine PM concentrations, and fewer regarding the effects on ship-related UFP concentrations, there is a lack of studies on passenger in-land ship transport-related UFP emissions, namely in estuaries in the vicinity of European capitals, specifically in the Mediterranean. [7] identifies domestic ferries as the main contributors to emissions among harbour vessels. [57] highlights that UFP represent an important fraction of low-sulphur fuel emissions and the need for future policies to take this factor into account.

This work aims to assess small passenger ships transport-related UFP concentrations in the immediate terminal's areas, in Tagus estuary, Lisbon, Portugal. These areas are located close to city centres, surrounded by residential, business, services and recreational areas and companies, among others.

\section{Data and Methods}

In recent years, a few studies have been carried out in Lisbon, Portugal, in order to evaluate air quality [68] [69] [70] [71] [72]. Plus, several measures have been implemented in areas highlighted as critical in order to accomplish air quality improvement [73]. However, the number of studies performed to assess UFP concentrations is very limited. Therefore, it is pertinent to evaluate their concentrations and find out the affected population degree of exposure. One of the main contributors to air pollution in Lisbon is road traffic [74] which is characterized by the emission of toxic particles and gases. However, in-land passenger ferries are also a pertinent emission source, far less addressed in those studies in the best of our knowledge. Nevertheless, the bottom-up approach used in the atmospheric emissions inventory for the Lisbon and Tagus Valley Region [71], considering the four main ferry connections between Lisbon and Tagus South shore (Cacilhas, Barreio, Montijo and Seixal), point for relevant emissions of $\mathrm{PM}_{10}$ and $\mathrm{PM}_{2.5}$ in the year 2014 as presented in Table 1. These results stress the increased need for a detailed analysis and evaluation of the UFP emissions.

Aiming to assess the influence of river passenger ships on urban and suburban air quality, particularly on UFP concentrations, a monitoring campaign was designed by choosing sampling sites in the vicinity of the ferry terminals. The strong influence of emissions from road traffic, as well as the intense ferries traffic, created a challenging monitoring environment. Furthermore, measurements

Table 1. Emissions of $\mathrm{PM}_{10}$ and $\mathrm{PM}_{2.5}$ in 2014 regarding the four main ferry connections between Lisbon and South Tagus shore.

\begin{tabular}{ccccc}
\hline Connection & Cacilhas & Barreiro & Montijo & Seixal \\
\hline $\mathrm{PM}_{2.5}[\mathrm{t} /$ year $]$ & 1.0 & 7.2 & 2.2 & 2.0 \\
$\mathrm{PM}_{10}[\mathrm{t} /$ year $]$ & 1.0 & 7.7 & 2.3 & 2.1 \\
\hline
\end{tabular}


were limited due to geographical conditions, access restrictions to ferries terminals and vicinity, equipment performance, and variable meteorological conditions.

\subsection{Context}

Passenger ferries provide a fast and comfortable alternative to cars, buses and trains for crossing the Tagus river. Ferry services play a particularly important role in the Lisbon Metropolitan Area (LMA), connecting North and South shores in Tagus Estuary, the largest in Western Europe. Data from April 2018 (https://www.amt-autoridade.pt/media/1655/relatorio-final_ação-fiscalização_so flusa.pdf) indicates that in 2016, commuter ferries provided service to 16 million passengers, shuttling them between the nine ferry terminals serving this network, shown in Figure 1. This service is provided by TTSL (Transtejo e Soflusa). The longest itinerary is between Montijo and Cais do Sodré $(13.8 \mathrm{~km})$, followed by Barreiro-Terreiro do Paço $(9.3 \mathrm{~km})$, Trafaria-PortoBrandão-Belém $(9.3 \mathrm{~km})$, Seixal-Cais do Sodré $(8.5 \mathrm{~km})$ and Cacilhas-Cais do Sodré $(2.2 \mathrm{~km})$.

Currently, the fleet is composed by 28 vessels: 18 catamarans, three ferries (catamaran) for passenger and cars, five passenger ferries (named "cacilheiros") and two monohull (https://ttsl.pt/terminais-e-frota/frota/). The power of the different vessels is presented in Figure 2(a). The hourly number of ferries cruising in Tagus by week-day, Saturday and Sunday/Holiday is presented in Figure 2(b), and the annual average trips associated with the different terminal connections is presented in Figure 2.

During week-days, the number of ferries cruising the Tagus river rounds 40 ships during the morning and evening rush hours $(8: 00 \mathrm{~h}$ and 18:00 $\mathrm{h}$, respectively), when most people uses this type of public transportation for commuting

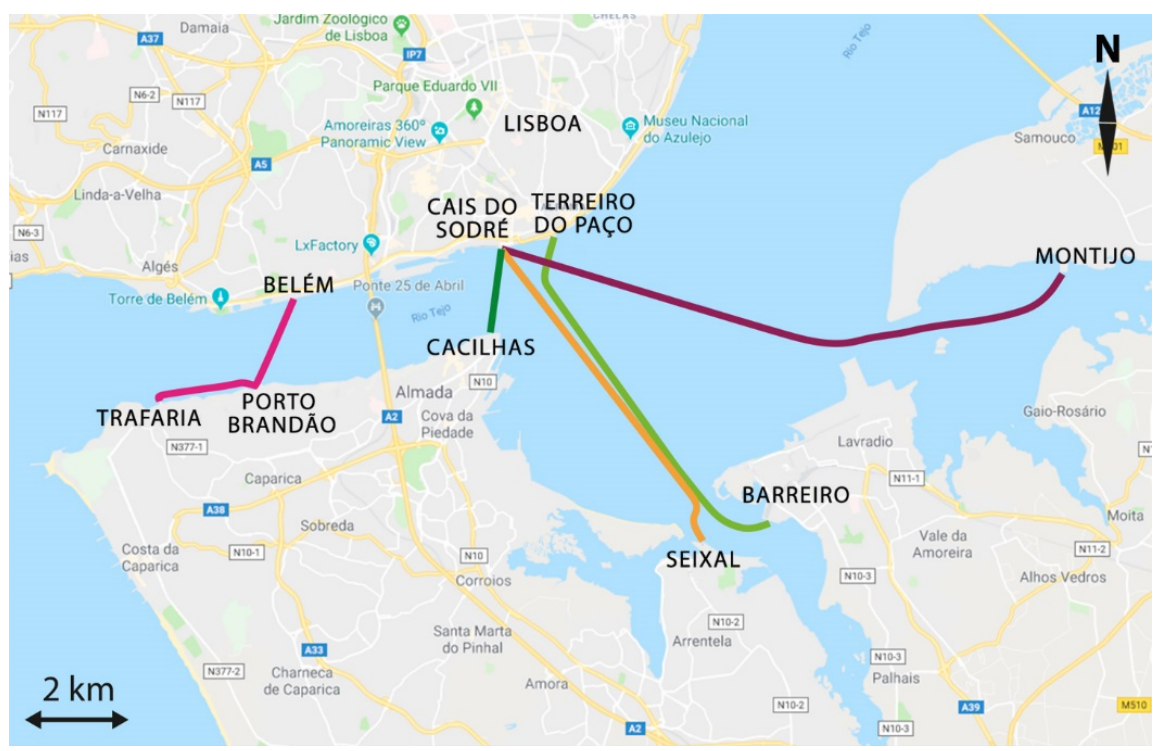

Figure 1. Map of the network of ferry terminals connecting the northern and southern shores of Tagus River (Maps source: https://www.google.pt/maps, last accessed on December 2018). 


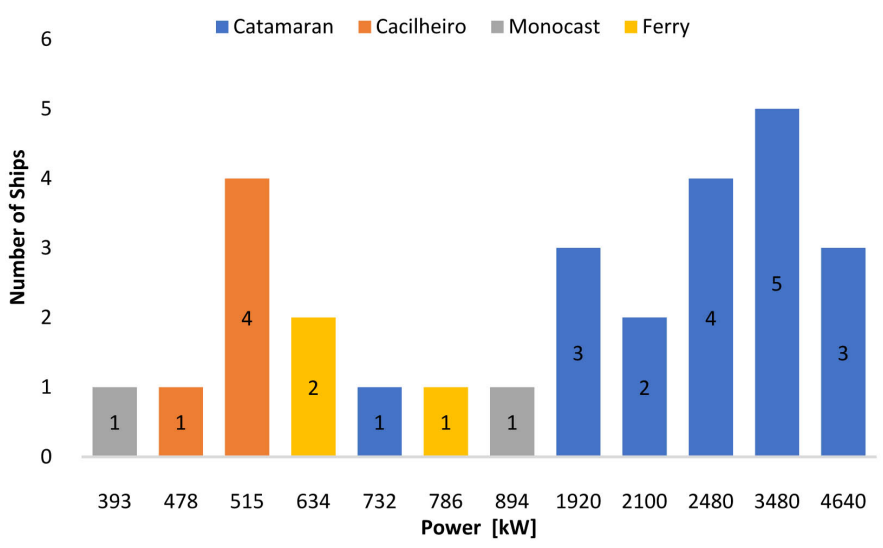

(a)

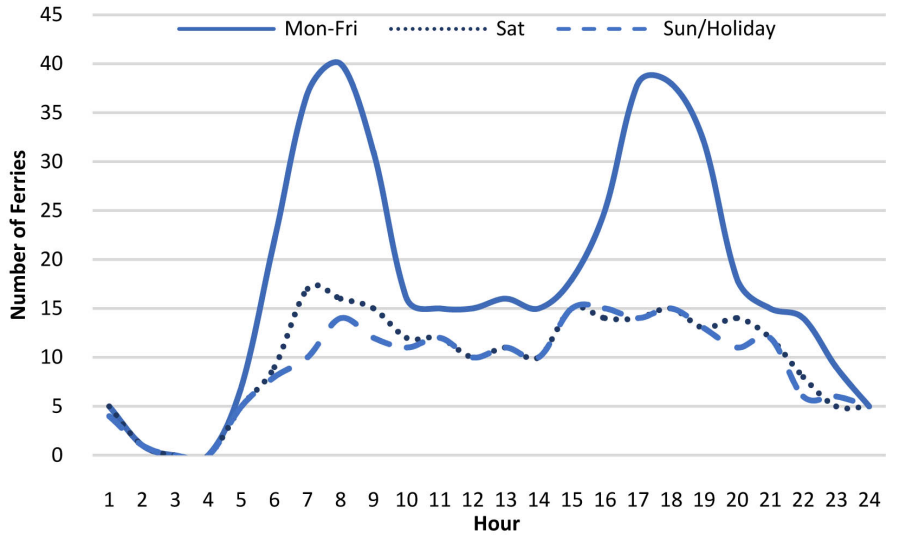

(b)

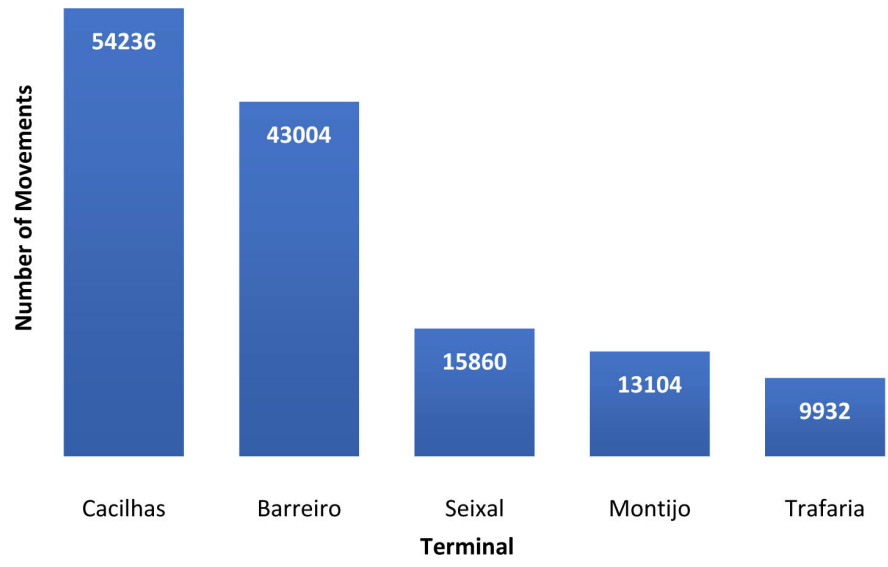

(c)

Figure 2. (a) Power, in kW, by type of ferry of the fleet operating in Tagus River, in LMA; (b) hourly number of ferries cruising in Tagus, LMA, by week-day, Saturday and Sunday/Holiday; (c) Annual average trips associated with the different terminal connections.

to work/school and back home. Nevertheless, even on weekends and holidays the number of commutes is between 10 and 15 ships each hour. Only during the night period, from 0:00 h to 5:00 h, operations are less than five, or even null. Connections between Cacilhas-Lisbon and Barreiro-Lisbon are from far the most frequent. 


\subsection{Monitoring Campaigns}

Measurements took place for non-consecutive 19 periods, reaching a total of $\sim 45$ hours of suitable measurements. Considering the goal of measuring the plume emitted by ferries and location of Lisbon ferry terminals (Cais do Sodré and Terreiro do Paço, Figure 1), it would be mandatory winds from a southern direction. We must stress that those synoptic situations are relatively scarce in Lisbon, where predominant winds are from the northern direction. In addition, both terminals are overmuch close to intense traffic roads and the frequency of number of arrivals and departures, sometimes continuous, would difficult the association between a ferry operation and its effect on UFP concentration. Furthermore, most of the available surrounding areas are public restricted. The combination of these factors disengaged any reliable measurements in Lisbon. Therefore, only the terminals in Tagus southern shore were analysed, namely Cacilhas, Barreiro, Seixal and Montijo. The southern terminals allowed measurements from the plumes emitted by the majority of TTSL ships currently cruising the Tagus river. Also, especially for Barreiro and Cacilhas, they register high number of ferry operations and, exception for Cacilhas, they are relatively away from other UFP sources. Additionally, the location of Seixal ferry terminal allows to assess the area of influence of ferry's path from/to Barreiro within the urban and sub-urban areas, therefore enabling the evaluation on ferry cruising on urban air quality, along the navigation path. Details about the location of each sampling site can be seen in Figure 3. Continuous lines indicate the ferry paths, shadowed triangles represent the manoeuvring and hoteling area, arrows designate the wind direction which allow the ferry plume measurement during

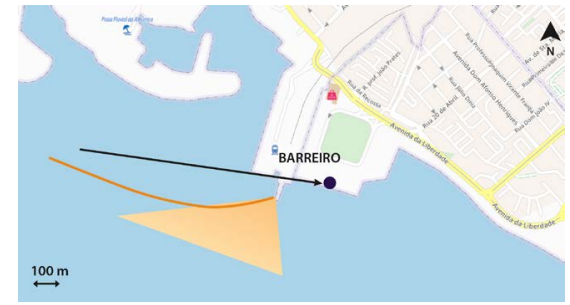

(a)

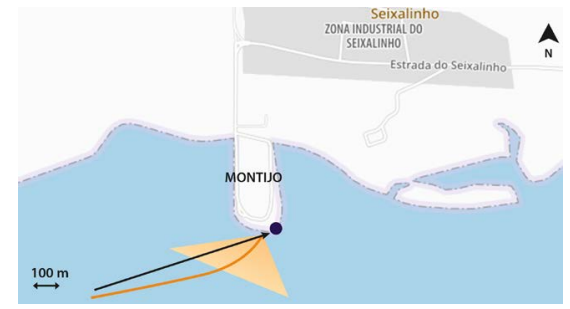

(c)

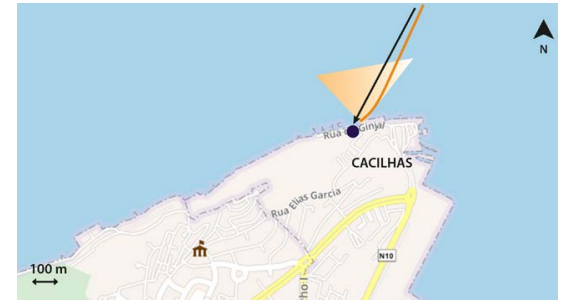

(b)

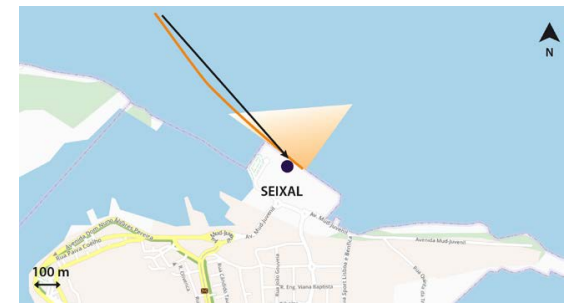

(d)

Figure 3. Location of the sampling sites (dots). Arrows indicate the downwind directions to cruising paths; Shadow triangles indicate the manoeuvring area; continuous lines indicate the ferry path. Top left-Cacilhas; top right-Barreiro; bottom left-Montijo and bottom right-Seixal (Maps source: https://www.viamichelin.pt/web/Mapas-plantas\#, last accessed on December 2018). 
cruising on the sampling site (dot). Both Montijo and Seixal ferry terminals are located in areas relatively far away from residential areas. Barreiro terminal is located closer to residential areas and Cacilhas terminal is located close to restaurants and residential areas.

Sampling site dates were chosen according to meteorological forecast aiming to maximize measurements under downwind conditions. Measurements were carried out on the street with one particle counter equipment. The monitoring equipment was handled by an expert. Each sampling site was properly geo-referenced: Barreiro (latitude 38.651139, longitude -9.077778), Cacilhas (latitude 38.688012, longitude -9.148781), Montijo (latitude 38.699612, longitude -9.005861) and Seixal (latitude 38.647605, longitude -9.095500). The height of the Mixing Layer (ML) was compiled from the atmospheric soundings, at 12:00 UTC over Lisbon (http://weather.uwyo.edu/upperair/sounding.html) for the sampling periods. All departures and arrivals during the sampling periods were checked on sight. The ferry model, technical characteristics and age were obtained from the TTSL site (https://ttsl.pt/terminais-e-frota/frota/). Meteorological parameters (temperature, wind intensity and direction, relative humidity) were also recorded with a portable meteorological station model Watch Dog 2700. Its temperature range is $-40^{\circ} \mathrm{C}$ to $125^{\circ} \mathrm{C}$, accuracy $\pm 0.3^{\circ} \mathrm{C}$, at $-40^{\circ} \mathrm{C}$ to $90^{\circ} \mathrm{C}$; relative humidity range is $10 \%$ to $100 \%$, at $5^{\circ} \mathrm{C}$ to $50^{\circ} \mathrm{C}$, accuracy $\pm 3 \%$ at $20 \%$ to $100 \%$ and $25^{\circ} \mathrm{C}$; wind speed range is 0.1 to $322 \mathrm{~km} \cdot \mathrm{h}^{-1}$, accuracy $\pm 3 \mathrm{~km} \cdot \mathrm{h}^{-1}$ and wind direction range $0^{\circ}$ to $330^{\circ}$, resolution $1^{\circ}$ and accuracy $\pm 3^{\circ}$.

Currently, from the 28 operational ferries, only 15 were identified during sampling periods, specified above ( $\sim 45$ hours of suitable measurements). Technical data of the identified ferries are resumed in Table 2 . The exhausting system in catamarans is close to water level while in all other ships are located at the top, emitting the exhaust plume of the ferry directly into ambient air. All ferries have engines classified as Diesel/High Speed.

\subsection{Sampling Equipment}

Ultrafine particles concentration is expressed as the number of particles by cubic centimetre $\left(\mathrm{pt} \cdot \mathrm{cm}^{-3}\right)$. UFP concentrations measurements were performed with the particle counter " $P$-Trak ${ }^{\otimes}$ Ultrafine Particle Counter, 8525". P-track is a portable measuring device which detects and counts, each second, particles with less than $1 \mu \mathrm{m}$ diameter present in a cubic centimetre volume of air by an optical method. Consequently, the particle number counting (PNC) is expressed in $\mathrm{pt} \cdot \mathrm{cm}^{-3}$. The particles captured in the inlet stream are mixed with alcohol vapour (isopropyl) allowing the microscopic particles in the air growth into larger droplets, easier to detect and count. This mixture passes through a condenser which promotes the condensation of the alcohol on the particle's surface, forming a droplet with enough size to diffuse visible light. Then the droplets pass through a laser beam where a light detector counts the number of light flashes produced. Each flash corresponds to a particle. Before sampling, it is mandatory 
Table 2. Technical data of the ships identified during sampling periods (https://ttsl.pt/terminais-e-frota/frota/).

\begin{tabular}{|c|c|c|c|c|c|c|c|}
\hline Ferry & Class & Length $[\mathrm{m}]$ & $\begin{array}{l}\text { Entry into } \\
\text { Service }\end{array}$ & Engine & $\begin{array}{c}\text { Power } \\
{[\mathrm{kW}]}\end{array}$ & $\begin{array}{c}\text { Service } \\
\text { Speed }[\mathrm{knot}]\end{array}$ & Propulsion \\
\hline \multicolumn{8}{|c|}{ Cacilhas $\leftrightarrow$ Cais do Sodré(1) } \\
\hline $\begin{array}{l}\text { Campolide Dafundo } \\
\text { Sintrense }\end{array}$ & Cacilheiro & 29.20 & $1980-1982$ & mtu8V 396 TC & 515 & 10 & Propellers Variable Pitch \\
\hline S. Jorge & Monohull & 49.94 & 1992 & mtu 12 V183 TE62 & 478 & 13 & Propellers of Step fixed \\
\hline \multicolumn{8}{|c|}{ Barreiro $\leftrightarrow$ Terreiro do Paço (catamaran) } \\
\hline $\begin{array}{l}\text { Antero de Quental } \\
\text { Damião de Goes }\end{array}$ & & & & & & & \\
\hline $\begin{array}{c}\text { Fernando Namora } \\
\text { Fernando Pessoa } \\
\text { Gil Vicente } \\
\text { Miguel Torga }\end{array}$ & Damen & 49.20 & 2003 & mtu 16V40000M70 & 3480 & 22 & 2 Hamilton water jets \\
\hline \multicolumn{8}{|c|}{ Montijo $\leftrightarrow$ Cais do Sodré (catamaran) } \\
\hline Castelo & Transcat & 45 & 1995 & MWM TBD 616 V16 & 1920 & 22 & 2 water jets Lips \\
\hline Aroeira & Transcat & 46.25 & 1998 & mtu 12V 396 & 2480 & 22 & 2 water jets Lips \\
\hline \multicolumn{8}{|c|}{ Seixal $\leftrightarrow$ Cais do Sodré (catamaran) } \\
\hline Aroeira S. Julião & Transcat & 46.25 & 1998 & mtu 12V 396 & 2480 & 22 & 2 water jets Lips \\
\hline Algés & Transcat & 45 & 1995 & MWM TBD 616 V16 & 1920 & 22 & 2 water jets Lips \\
\hline Pedro Nunes & Austral & 37.4 & 2002 & $\mathrm{mtu} 12 \mathrm{~V} 2000 \mathrm{M} 70$ & 2100 & 22 & 2 water jets Hamilton \\
\hline
\end{tabular}

${ }^{(1)}$ During rush hours the fleet may be complemented by catamarans, class Transcat, $2480 \mathrm{~kW}$.

to verify that the counter is operating normally. For this purpose, it is used an HEPA zero filter [75]. This filter is attached to the counter and it should register zero in a few seconds. P-Trak concentration range is 0 to $5 \times 10^{5} \mathrm{pt} \cdot \mathrm{cm}^{-3}$ for particles range size 0.02 to $1 \mu \mathrm{m}$. Its sampling flow is $100 \mathrm{~cm}^{3} \cdot \mathrm{min}^{-1}$ and operation temperature range is $0^{\circ} \mathrm{C}$ to $38^{\circ} \mathrm{C}$.

Although P-Trak ${ }^{\oplus}$ measures particles less than $1 \mu \mathrm{m}$ size, and UFP are defined as particles with a diameter less than $100 \mathrm{~nm}$, interference will be minimal. Unlike mass concentrations, PNC consists mainly of particles smaller than 0.1 $\mu \mathrm{m}[76]$. Further details about the sampling equipment may be found in P-Trak ${ }^{\oplus}$, 2013.

\subsection{Data Analysis}

Due to synoptic and geographical constrains, measurements were mostly done downwind, allowing for a more robust analysis.

Averages of PNC over the period of 1-minute were plotted considering the temporal window from 1-minute before and after arrivals/departures. Linear regressions considering site by site data were performed using the Least Squares Method to access correlations between 1-minute PNC averages and meteorological parameters, namely temperature, relative humidity, wind speed and mixing layer height. Aiming to access correlation between PNC and ferry opera- 
tions, linear regressions between 1-hour PNC averages and number of ferry operations during that period were also performed. Regression was made with a 95\% confidence level. Furthermore, ANOVA analysis between periods with and without ferry operations was also performed, also with $95 \%$ confidence level. Associations between PNC and different classes of ferries were also evaluated.

\section{Results and Discussion}

There are substantial different characteristics among the sampling sites. Therefore, the results and discussion will be performed by site.

Obtained 1-minute PNC averages by site and under downwind conditions are plotted in Figure $4\left(1^{\text {st }}\right.$ quartile, average $(X)$, median $(-), 3^{\text {rd }}$ quartile and outliers (dots). The whiskers extend up from the top of the box to the largest data element that is less than or equal to 1.5 times the interquartile range (IQR) and down from the bottom of the box to the smallest data element that is larger than 1.5 times the IQR). Higher dispersion values were obtained for Cacilhas and Seixal (standard deviation (SD) $11.92 \times 10^{3} \mathrm{pt} \cdot \mathrm{cm}^{-3}$ and $11.76 \times 10^{3} \mathrm{pt} \cdot \mathrm{cm}^{-3}$, respectively). Higher mean and median $\left(21.09 \times 10^{3} \mathrm{pt} \cdot \mathrm{cm}^{-3}\right.$ and $16.2 \times 10^{3}$ $\mathrm{pt} \cdot \mathrm{cm}^{-3}$, respectively) were found in Cacilhas and the higher maximum $(70.05 \times$ $10^{3} \mathrm{pt} \cdot \mathrm{cm}^{-3}$ ) was obtained in Seixal. Minimum PNC values are lower in Montijo. Cacilhas presents the highest maximum PNC.

PNC during the immediate eight minutes before arrivals, eight minutes after departures and eight minutes before and after ferry occurrences, are plotted in Figure 5. During rush periods, there are many ferry occurrences in Cacilhas and Barreiro, in average two every 10 minutes. Therefore, a time lag larger than 8 minutes would excessively overlap PNC related to ferry occurrences.

As shown in Figure 5, during the third minute around a ferry occurrence, PNC are considerably higher when compared to the lowest value during this 8-minute period, ranging from $25 \%$ higher in Barreiro to $197 \%$ in Cacilhas.

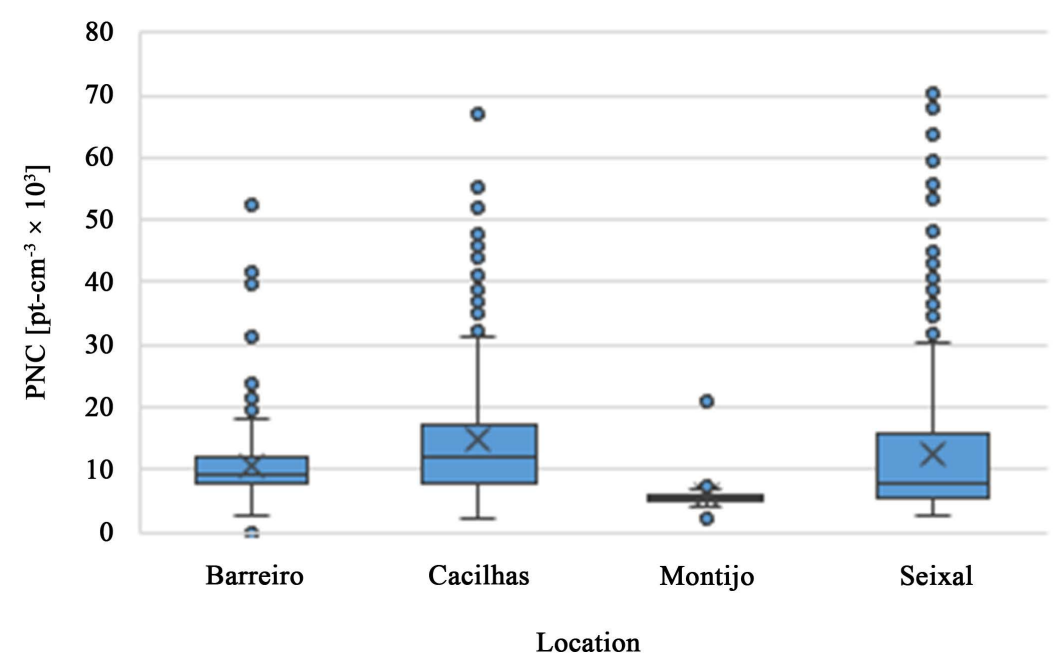

Figure 4. Boxplot of 1-minute PNC mean distribution by site, under downwind conditions. 


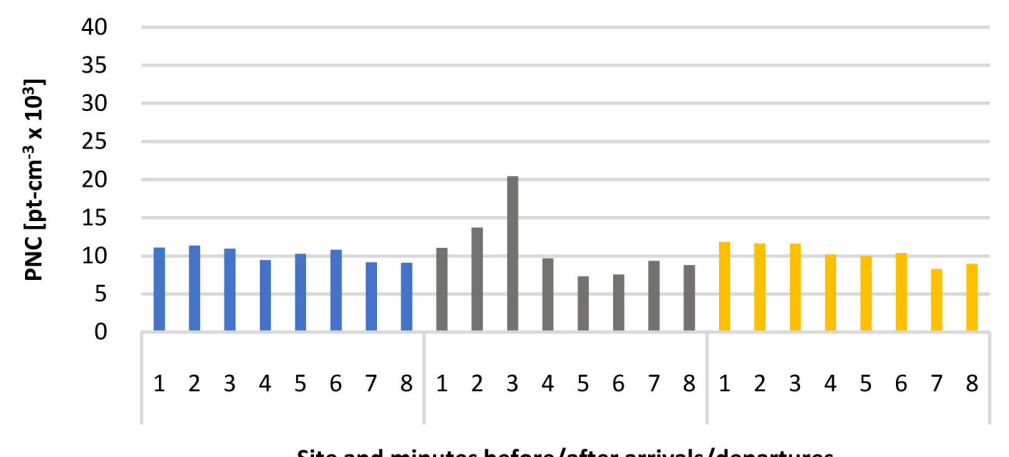

Site and minutes before/after arrivals/departures

(a)

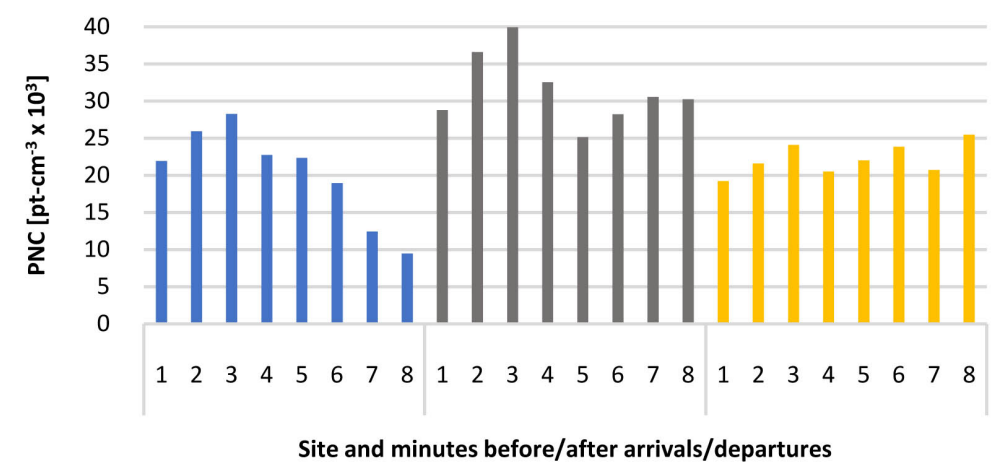

(b)

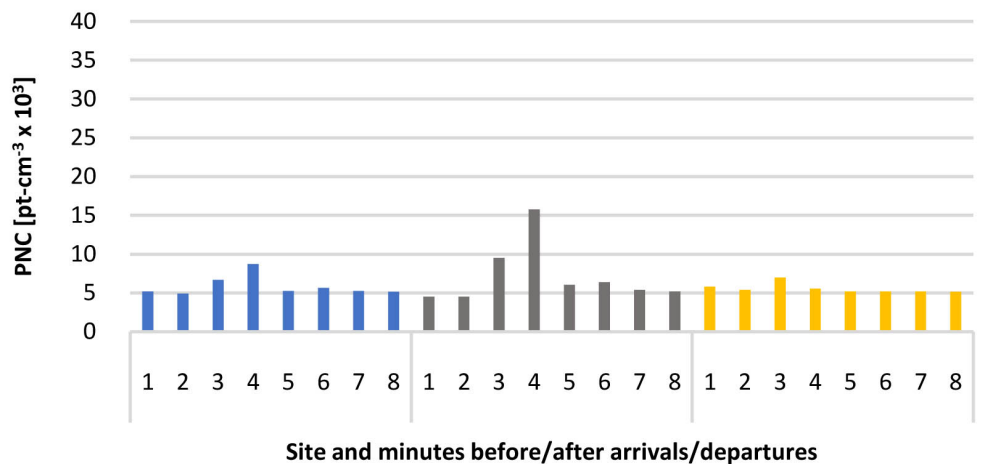

(c)

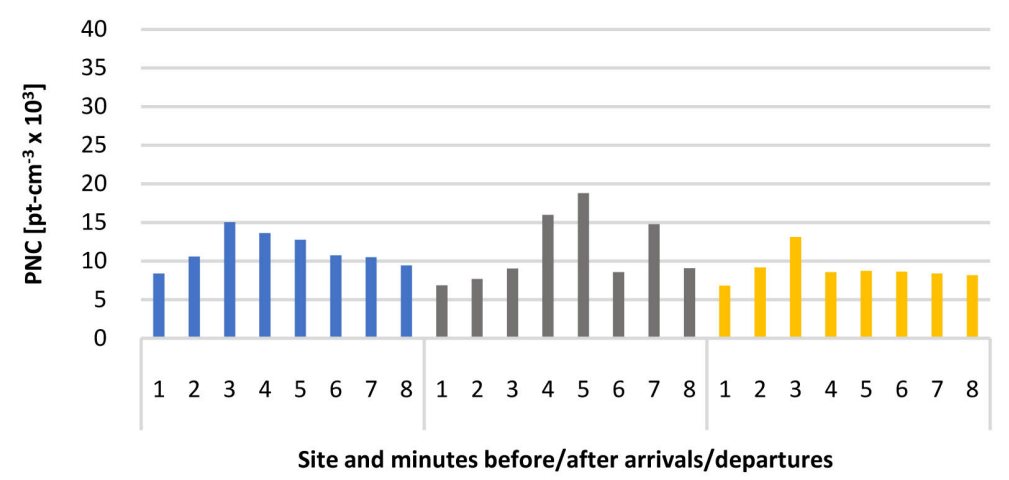

(d)

Figure 5. Site by site PNC during the immediate eight minutes before/after ferry operations (blue), eight minutes before departures (grey), eight minutes after arrivals (yellow). (a) Barreiro; (b) Cacilhas; (c) Montijo; (d) Seixal. 
During the same period, departures are responsible in all the ports for a higher increase in PNC than arrivals (Figure 5). Given the almost constant ferry operations in the Barreiro terminal, with the consequent continuous emission of UFP, departure and arrival PNC values are believed to be underestimated. Nevertheless, they clearly show an increase of PNC as a result of departures and arrivals.

Except for Montijo, results from regression analysis (Table 3) show high positive correlations ( $r$ ) between 1-hour PNC averages and the number of ferry occurrences. This result highlights that in-land ferries contribute to elevated PNC downwind to ferry's path, as previously concluded by López-Aparicio et al. (2017). Montijo, although also presents high correlation coefficient, although not statistically significant. This fact can be explained by the reduced number of ferries operating in this connection, comparatively to the other three terminals. Comparing the obtained results for departures and arrivals for the four terminals, departures have a significant and higher positive correlation value than arrivals in Barreiro, Cacilhas and Seixal, and both are statistically significant: $r=$ 0.80 to $r=0.93, p \leq 0.01$, for departures, and $r=0.76$ to $0.88, p \leq 0.02$, for arrivals. The exception again is Montijo, which presents non-significant correlations values. The obtained results from regression analysis between 1-minute PNC averages and wind speed were different for each analysed terminal, with 4) Montijo and Barreiro presenting not statistically significant correlations, and 2) Cacilhas and Seixal showing very high negative statistically significant correlations. The correlation results in the Barreiro can be explained by the reduced wind speed range during sampling periods in this site $\left(0,1\right.$ and $\left.4 \mathrm{~km} \cdot \mathrm{h}^{-1}\right)$. Results did not show significant correlations between PNC and other meteorological parameters (temperature, relative humidity and mixing layer height).

Table 3. Obtained results of PNC increase with ferry operations, regression analysis between PNC averages and ferry occurrences and wind speed and ANOVA analysis between periods with and without ferry operations.

\begin{tabular}{|c|c|c|c|c|c|c|}
\hline \multicolumn{3}{|l|}{ Site } & \multirow{2}{*}{$\begin{array}{l}\text { Barreiro } \\
25 \%\end{array}$} & \multirow{2}{*}{$\begin{array}{l}\text { Cacilhas } \\
197 \%\end{array}$} & \multirow{2}{*}{$\begin{array}{l}\text { Montijo } \\
69 \%\end{array}$} & \multirow{2}{*}{$\begin{array}{l}\text { Seixal } \\
79 \%\end{array}$} \\
\hline PNC & Ferry Occurre & & & & & \\
\hline \multirow{2}{*}{$\begin{array}{l}\text { Increments } \\
\text { during }\end{array}$} & Departures & & $179 \%$ & $59 \%$ & $249 \%$ & $170 \%$ \\
\hline & Arrivals & & $43 \%$ & $25 \%$ & $35 \%$ & $79 \%$ \\
\hline \multirow{8}{*}{$\begin{array}{l}\text { Regression } \\
\text { Analysis }\end{array}$} & Ferry & $\mathrm{r}$ & 0.79 & 0.91 & \multirow{2}{*}{ NSS } & 0.94 \\
\hline & Occurrences & $\mathrm{p}$ & $<0.01$ & 0.02 & & $<0.01$ \\
\hline & \multirow{2}{*}{ Departures } & $\mathrm{r}$ & 0.80 & 0.92 & \multirow{2}{*}{ NSS } & 0.93 \\
\hline & & $\mathrm{p}$ & $<0.01$ & 0.01 & & $<0.01$ \\
\hline & \multirow{2}{*}{ Arrivals } & $\mathrm{r}$ & 0.76 & 0.88 & \multirow{2}{*}{ NSS } & \multirow{2}{*}{ NSS } \\
\hline & & $\mathrm{p}$ & 0.01 & 0.02 & & \\
\hline & \multirow{2}{*}{ Wind Speed } & $\mathrm{r}$ & \multirow{2}{*}{ NSS } & -0.93 & \multirow{2}{*}{ NSS } & -0.85 \\
\hline & & $\mathrm{p}$ & & $<0.01$ & & $<0.01$ \\
\hline $\operatorname{ANOVA}^{(1)}$ & & $\mathrm{p}$ & $<0.01$ & $<0.01$ & 0.04 & NSS \\
\hline
\end{tabular}

NSS-Not statistically significant. ${ }^{(1)}$ Analysis between PNC in periods with ferry operations and without ferry operations. 
Finally, the ANOVA analysis between measured PNC during periods with and without ferries operations show a statistically significant $(\mathrm{p}<0.01)$ difference between PNC averages for all terminals except for Seixal. However, the lack of statistically significant result in Seixal may be explained by the high frequency of Barreiro's ferries which plumes are measured in this site. This result suggests that ferries emissions are responsible for a significant PNC increase, in accordance to what was concluded for ships by [56] and [57].

As shown in Figure 6(b), Barreiro and Seixal terminals are located close to each other and the ferries from/to Barreiro path is close to Seixal terminal (approximately $650 \mathrm{~m}$ distance). In Seixal, for wind direction range from $\mathrm{N}$ to $\mathrm{NE}$, PNC results exclusively from plumes emitted by Barreiro's ferries. As it is shown in Figure 6(a), the maximum PNC averages are measured for wind speed range 6 to $8 \mathrm{~km} \cdot \mathrm{h}^{-1}$. Considering this wind speed range, PNC values obtained in Seixal are higher than PNC measured in Barreiro's terminal: arrivals, $30 \times 10^{3} \mathrm{pt} \cdot \mathrm{cm}^{-3}$ in Seixal and $10 \times 10^{3} \mathrm{pt} \cdot \mathrm{cm}^{-3}$ in Barreiro; departures, $35 \times 10^{3} \mathrm{pt} \cdot \mathrm{cm}^{-3}$ in Seixal and $20 \times 10^{3} \mathrm{pt} \cdot \mathrm{cm}^{-3}$ in Barreiro. In accordance to previous results, obtained PNC is slightly higher for departures than arrivals from/to Barreiro. This result might be explained by the way the exhaust gases are emitted, close to the water

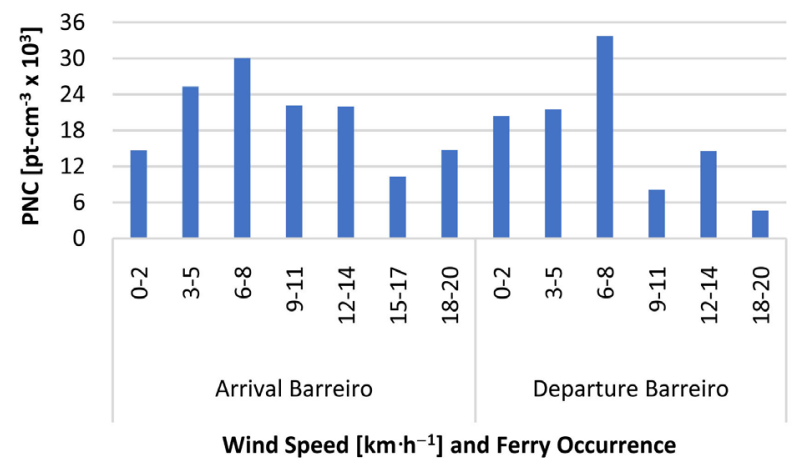

(a)

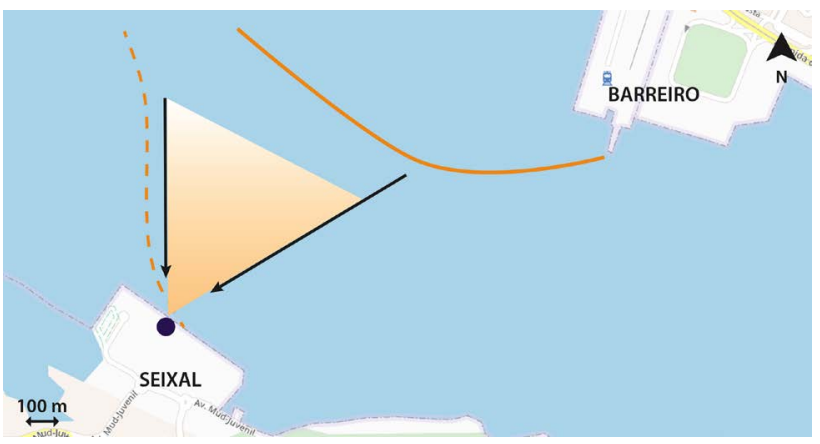

(b)

Figure 6. (a) Average PNC of ferries from/to Barreiro measured in Seixal as function of wind speed and under wind direction range from $\mathrm{N}$ to NE; (b) Detail of Barreiro and Seixal geographical location. Plumes emitted by Barreiro's ferries affect PNC on Seixal when wind direction range from NE to NW. Shadowed triangle shows the wind direction range in which only plumes emitted by Barreiro's ferries are measurable in Seixal; the continuous and dashed lines show the ferries paths from Barreiro and Seixal, respectively. 
level at the rear of the ship. During cruise phase, the water flow generated is laminar and the plume is emitted into ambient air; during manoeuvring and hoteling phases, water flow generated by ferry engines is turbulent, which prevents the plume full dispersion into ambient air, leading to lower UFP emissions.

Figure 7 shows pollution roses in each ferry terminal during sampling periods, regardless of downwind or non-downwind direction. Except for Montijo, the highest PNC is obtained in downwind direction. In Barreiro, there are higher PNC levels measured from NW which are similar to the ones measured under downwind, probably resulting from de ferry cruising after shifting direction to NNE (please see Figure 1). In Montijo, the highest PNC was obtained for non-downwind direction, suggesting the existence of in-land UFP sources with more impact on PNC than de ferries.

PNC averages obtained in each ferry terminal, by class of ferry are presented in Figure 8. The highest PNC are associated with Cacilheiros $\left(30 \times 10^{3} \mathrm{pt} \cdot \mathrm{cm}^{-3}\right)$

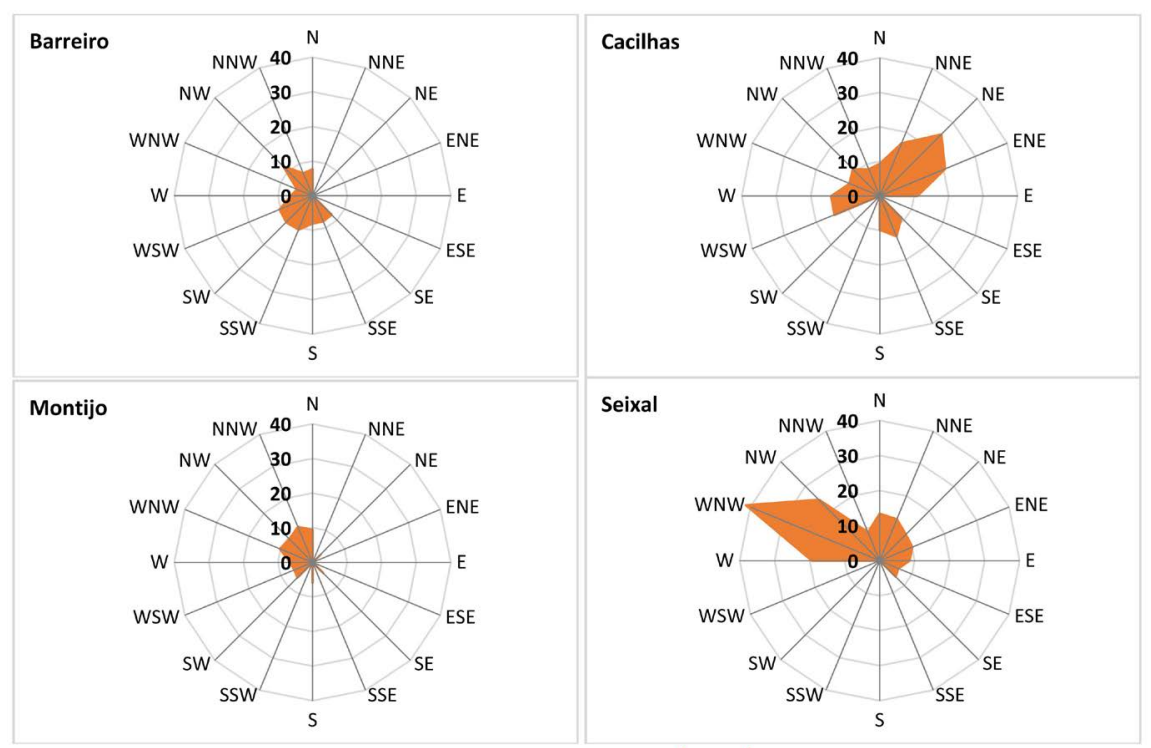

Figure 7. PNC rose pollution in each ferry terminal $\left(\mathrm{pt} \cdot \mathrm{cm}^{-3} \times 10^{3}\right)$.

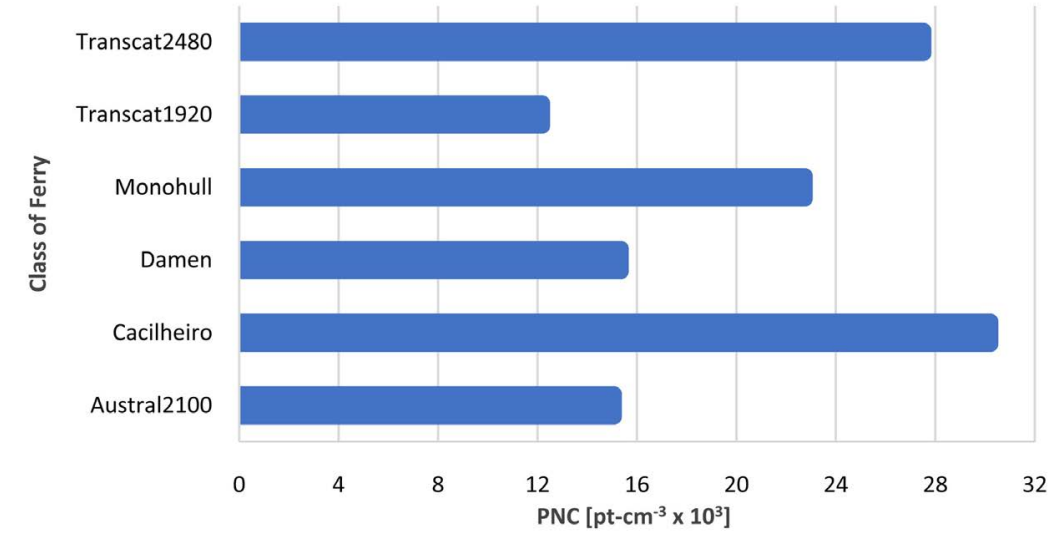

Figure 8. Obtained PNC average for different class of ferry operating among the four terminals studied, downwind. 
Transcat with power of $2480 \mathrm{~kW}\left(28 \times 10^{3} \mathrm{pt} \cdot \mathrm{cm}^{-3}\right)$ and monohull $\left(23 \times 10^{3}\right.$ $\left.\mathrm{pt} \cdot \mathrm{cm}^{-3}\right)$. The other ferries present figures from $12 \times 10^{3} \mathrm{pt} \cdot \mathrm{cm}^{-3}$ to $15 \times 10^{3}$ $\mathrm{pt} \cdot \mathrm{cm}^{-3}$. Nevertheless, as highlighted before, UFP emitted during cruising are expected to be higher than in terminals and these figures should be interpreted only as a magnitude order.

Our findings are in good accordance with results obtained in studies of PNC related to ship transport: increase of PNC in the vicinity and downwind to harbour [4] [40] [41] [42] [43] [46] and in coastal areas [4] [5] [7] [46]. However, as mentioned above, there are no studies devoted to evaluate the PNC associated with in-land ferries emissions, although there are similar studies to other types of MT (e.g. [40] [41] [42]). Though, the dimension of the ships is completely different; this work is focused on small ferries while the mentioned studies are focused on larger ships and vessels.

\section{Conclusions}

The present work aimed to evaluate the impact of passenger ferries on PNC in locations nearby terminals and along shore of ferries' navigation paths. Sampling sites were chosen in the vicinity of four ferry terminals in South Tagus shore in Lisbon, Portugal.

The results point out that PNC increases with the number of ferry operations during the minutes before or after arrivals or departures, respectively. The highest PNC was recorded in Cacilhas, where average PNC, three minutes after departures, was $40 \times 10^{3} \mathrm{pt} \cdot \mathrm{cm}^{-3}$. The lowest was recorded in Montijo, $15 \times 10^{3}$ $\mathrm{pt} \cdot \mathrm{cm}^{-3}$, also three minutes after departures. Both Barreiro and Seixal present similar figures, approximately $20 \times 10^{3} \mathrm{pt} \cdot \mathrm{cm}^{-3}$, four and five minutes after departures, respectively.

Results show moderate to high positive correlations between PNC values and the number of ferry trips $(r=0.79$ to $r=94, p \leq 0.02)$. Ferries contribute to short-time elevated PNC values downwind to the ferries' navigation paths, especially for departures. Except for Seixal, there are significant differences in PNC averages between periods with and without ferry operations. This fact highlights that UFP emitted by ferries contributes to PNC increase. High negative correlations $(r=-0.85$ and $r=-0.93)$ between PNC and wind intensity were also found.

Regarding ferries' class and age, higher PNC values were found for older engines or more powerful engines. However, the gas exhausting system in oldest ferries is located on top of the ferry, which promotes better plume dispersion. For this reason, this result must be looked at with caution. Regarding catamarans class Damen, higher PNC was found downwind and along the cruising path $\left(30 \times 10^{3} \mathrm{pt} \cdot \mathrm{cm}^{-3}\right.$ to $\left.35 \times 10^{3} \mathrm{pt} \cdot \mathrm{cm}^{-3}\right)$ than in ferries' terminals. This result highlights that, for catamarans, UFP emissions during navigation are higher than during manoeuvring and hoteling. Therefore, downwind and under very weak wind $\left(6\right.$ to $8 \mathrm{~km} \cdot \mathrm{h}^{-1}$ ) conditions, PNC along shore path is expected to be higher than in ferries' terminals. 
Finally, to the best of our knowledge, there are no published studies on PNC emitted by small in-land water bodies ferries. Therefore, our findings could not be properly compared to other results, and the current paper makes a unique contribution for a better understanding of the air quality impacts of this transport mode.

These results highlight that people working in ferry terminals or living downwind, along the navigation path, are exposed to high PNC values. Additionally, most passengers use ferries on a daily basis as a commutant mode, although for shorter periods. Nevertheless, their exposure to UFP during the period of permanence in terminal should not be neglected. Obtained results reveal the possibility of using the developed methodology to monitor the exposure to ultrafine particles in the surrounding urban area of in-land passenger ferries, namely in the present context of increasing number of ferry movement on Tagus river.

\section{Acknowledgements}

The authors would like to thank the TTSL (Transtejo e Soflusa) for giving us access to a private location for measurements in ferry terminal of Montijo. The research work of CENSE is financed by Fundação para a Ciência e Tecnologia, I.P., Portugal (UID/AMB/04085/2019).

\section{Conflicts of Interest}

The authors declare no conflicts of interest regarding the publication of this paper.

\section{References}

[1] UNCTAD (2018) Review of Maritime Transport 2018 (UNCTAD/RMT/2018). https://unctad.org/en/PublicationsLibrary/rmt2018_en.pdf

[2] Marmer, E. and Langmann, B. (2005) Impact of Ship Emissions on the Mediterranean Summertime Pollution and Climate: A Regional Model Study. Atmospheric Environment, 39, 4659-4669. https://doi.org/10.1016/j.atmosenv.2005.04.014

[3] US-EPA (2009) Proposal to Designate an Emission Control Area for Nitrogen Oxides, Sulfur Oxides and Particulate Matter. Technical Support Document, Chapter 3: Impacts of Shipping Emissions on Air Quality, Health and the Environment. U.S. Environmental Protection Agency, Assessment and Standards Division, Washington DC.

[4] Viana, M., Hammingh, P., Colette, A., Querol, X., Degraeuwe, B., de Vlieger, I. and van Aardenne, J. (2014) Impact of Maritime Transport Emissions on Coastal Air Quality in Europe. Atmospheric Environment, 90, 96-105. https://doi.org/10.1016/j.atmosenv.2014.03.046

[5] Westerlund, J., Hallquist, M. and Hallquist, Å.M. (2015) Characterization of Fleet Emissions from Ships through Multi-Individual Determination of Size-Resolved Particle Emissions in a Coastal Area. Atmospheric Environment, 112, 159-166. https://doi.org/10.1016/j.atmosenv.2015.04.018

[6] Zimmerman, N., Wang, J.M., Jeong, C.-H., Wallace, J.S. and Evans, G.J. (2016) Assessing the Climate Trade-Offs of Gasoline Direct Injection Engines. Environmental Science \& Technology, 50, 8385-8392. https://doi.org/10.1021/acs.est.6b01800 
[7] López-Aparicio, S., Tønnesen, D., Thanh, T.N. and Neilson, H. (2017) Shipping Emissions in a Nordic Port: Assessment of Mitigation Strategies. Transportation Research Part D, 53, 205-216. https://doi.org/10.1016/j.trd.2017.04.021

[8] Becerril-Valle, M., Coz, E., Prévôt, A.S.H., Močnik, G., Pandis, S.N., Sánchez de la Campa, A.M., Alastuey, A., Díaz, E., Pérez, R.M. and Artíñano, B. (2017) Characterization of Atmospheric Black Carbon and Co-Pollutants in Urban and Rural Areas of Spain. Atmospheric Environment, 169, 36-53.

https://doi.org/10.1016/j.atmosenv.2017.09.014

[9] Kumar, P., Morawska, L., Birmili, W., Paasonen, P., Hu, M., Kulmala, M., Harrison, R.M., Norford, L. and Britter, R. (2014) Ultrafine Particles in Cities. Environment International, 66, 1-10. https://doi.org/10.1016/j.envint.2014.01.013

[10] Albuquerque, P., Gomes, J. and Bordado, J. (2012) Assessment of Exposure to Airborne Ultrafine Particles in the Urban Environment of Lisbon, Portugal. Journal of the Air \& Waste Management Association, 62, 373-380.

https://doi.org/10.1080/10962247.2012.658957

[11] WHO (2013) World Health Organization-Health Effects of Particulate Matter. http://www.euro.who.int/_data/assets/pdf_file/0006/189051/Health-effects-of-parti culate-matter-final-Eng.pdf

[12] Sioutas, C., Delfino, R. and Singh, M. (2005) Exposure Assessment for Atmospheric Ultrafine Particles (UFPs) and Implications in Epidemiologic Research. Environmental Health Perspectives, 113, 947-955. https://doi.org/10.1289/ehp.7939

[13] Ezz, W., Mazaheri, M., Robinson, P., Johnson, G., Clifford, S., He, C., Morawska, L. and Marks, G. (2015) Ultrafine Particles from Traffic Emissions and Children's Health (UPTECH) in Brisbane, Queensland (Australia): Study Design and Implementation. International Journal of Environmental Research and Public Health, 12, 1687-1702. https://doi.org/10.3390/ijerph120201687

[14] Peters, A., Wichmann, E., Tuch, T., Heinrich, J. and Heyder, J. (1997) Respiratory Effects Are Associated with the Number of Ultrafine Particles. American Journal of Respiratory and Critical Care Medicine, 155, 1376-1383. https://doi.org/10.1164/ajrccm.155.4.9105082

[15] Penttinen, P., Timonen, K., Tiittanen, P., Mirme, A., Ruuskanen, J. and Pekkanen, J. (2001) Number Concentration and Size of Particles in Urban Air: Effects on Spirometric Lung Function in Adult Asthmatic Subjects. Environmental Health Perspectives, 109, 319-323. https://doi.org/10.1289/ehp.01109319

[16] Semmler, M., Seitz, J., Erbe, F., Mayer, P., Heyder, J., Oberdorster, G. and Kreyling, W. (2004) Long-Term Clearance Kinetics of Inhaled Ultrafine Insoluble Iridium Particles from the Rat Lung, Including Transient Translocation into Secondary Organs. Inhalation Toxicology, 16, 453-459.

https://doi.org/10.1080/08958370490439650

[17] Geiser, M., Rothen-Rutishauser, B., Kapp, N., Schürch, S., Kreyling, W., Schulz, H., Semmler, M., Hof, V., Heyder, J. and Gehr, P. (2005) Ultrafine Particles Cross Cellular Membranes by Nonphagocytic Mechanisms in Lungs and in Cultured Cells. Environmental Health Perspectives, 113, 1555-1560. https://doi.org/10.1289/ehp.8006

[18] Carosino, C., Bein, K., Plummer, L., Castaneda, A., Zhao, Y., Wexler, A. and Pinkerton, K. (2015) Allergic Airway Inflammation Is Differentially Exacerbated by Daytime and Nighttime Ultrafine and Submicron Fine Ambient Particles: Hemeoxygenase-1 as an Indicator of PM-Mediated Allergic Inflammation. Journal of Toxicology and Environmental Health, Part A, 78, 254-266. 
https://doi.org/10.1080/15287394.2014.959627

[19] Lanzinger, S., Schneider, A., Breitner, S., Stafoggia, M., Erzen, I., Dostal, M. and Peters, A. (2016) Associations between Ultrafine and Fine Particles and Mortality in Five Central European Cities-Results from the UFIREG Study. Environment International, 88, 44-52. https://doi.org/10.1016/j.envint.2015.12.006

[20] Terzano, C., Di Stefano, F., Conti, V., Graziani, E. and Petroianni, A. (2010) Air Pollution Ultrafine Particles: Toxicity beyond the Lung. European Review for Medical and Pharmacological Sciences, 14, 809-821.

[21] Stanek, L., Sacks, J., Dutton, S. and Dubois, J. (2011) Attributing Health Effects to Apportioned Components and Sources of Particulate Matter: An Evaluation of Collective Results. Atmospheric Environment, 45, 5655-5663.

https://doi.org/10.1016/j.atmosenv.2011.07.023

[22] Slezakova, K., Alvim-Ferraz, M. and Pereira, M. (2012) Elemental Characterization of Indoor Breathable Particles at a Portuguese Urban Hospital. Journal of Toxicology and Environmental Health, Part A, 75, 909-919. https://doi.org/10.1080/15287394.2012.690707

[23] Ferreira, A., Cemlyn-Jones, J. and Cordeiro, C. (2013) Nanoparticles, Nanotechnology and Pulmonary Nanotoxicology. Revista Portuguesa de Pneumologia, 19, 28-37. https://doi.org/10.1016/j.rppneu.2012.09.003

[24] Gomes, J., Bordado, J. and Albuquerque, P. (2012) Monitoring Exposure to Airborne Ultrafine Particles in Lisbon, Portugal. Inhalation Toxicology, 24, 425-433. https://doi.org/10.3109/08958378.2012.684077

[25] César, A., Nascimento, L., Mantovani, K. and Pompeo Vieira, L. (2016) Fine Particulate Matter Estimated by Mathematical Model and Hospitalizations for Pneumonia and Asthma in Children. Revista Paulista de Pediatria (English Edition), 34, 18-23. https://doi.org/10.1016/j.rppede.2015.12.005

[26] Buonanno, G., Giovinco, G., Morawska, L. and Stabile, L. (2015) Lung Cancer Risk of Airborne Particles for Italian Population. Environmental Research, 142, 443-451. https://doi.org/10.1016/j.envres.2015.07.019

[27] Grana, M., Toschi, N., Vicentini, L., Pietroiusti, A. and Magrini, A. (2017) Exposure to Ultrafine Particles in different Transport Modes in the City of Rome. Environmental Pollution, 228, 201-210. https://doi.org/10.1016/j.envpol.2017.05.032

[28] IARC (2014) Diesel and Gasoline Engine Exhausts and Some Nitroarenes. IARC Monographs on the Evaluation of Carcinogenic Risks to Humans No. 105. International Agency for Research on Cancer, Lyon.

https://monographs.iarc.fr/wp-content/uploads/2018/06/mono105.pdf

[29] Ebisu, K., Berman, J. and Bell, M. (2016) Exposure to Coarse Particulate Matter during Gestation and Birth Weight in the U.S. Environment International, 94, 519-524. https://doi.org/10.1016/j.envint.2016.06.011

[30] Shah, A., Langrish, J., Nair, H., McAllister, D., Hunter, A., Donaldson, K., Newby, D. and Mills, N. (2013) Global Association of Air Pollution and Heart Failure: A Systematic Review and Meta-Analysis. The Lancet, 382, 1039-1048. https://doi.org/10.1016/S0140-6736(13)60898-3

[31] Holland, M. (2014) Cost-Benefit Analysis of Final Policy Scenarios for the EU Clean Air Package. Version 2 (Corresponding to IIASA TSAP Report \#11, Version 2a). http://ec.europa.eu/environment/air/pdf/TSAP\%20CBA.pdf

[32] Reche, C., Viana, M., Moreno, T., Querol, X., Alastuey, A., Pey, J. and Richard, A. (2011) Peculiarities in Atmospheric Particle Number and Size-Resolved Speciation 
in an Urban Area in the Western Mediterranean: Results from the DAURE Campaign. Atmospheric Environment, 45, 5282-5293.

https://doi.org/10.1016/j.atmosenv.2011.06.059

[33] Liggio, J., Gordon, M., Smallwood, G., Li, S.-M., Stroud, C., Staebler, R., Lu, G., Lee, P., Taylor, B. and Brook, J. (2012) Are Emissions of Black Carbon from Gasoline Vehicles Underestimated? Insights from Near and On-Road Measurements. Environmental Science \& Technology, 46, 4819-4828.

https://doi.org/10.1021/es2033845

[34] Fiore, A.M., Naik, V., Spracklen, D.V., Steiner, A., Unger, N., Prather, M., Bergmann, D., Cameron.Smith, P.J., Cionni, I., Collins, W.J., Eyring, V., Folberth, G.A., Ginoux, P., Horowitz, L.W., Josse, B., Lamarque, J.-F., MacKenzie, I.A., Nagashima, T., O’Connor, F.M., Righi, M., Rumbold, S.T., Shindell, D.T., Skeie, R.B., Sudo, K., Szopa, S., Takemura, T. and Zeng, G. (2012) Global Air Quality and Climate. Chemical Society Reviews, 41, 6663-6683. https://doi.org/10.1039/c2cs35095e

[35] Booth, B. and Bellouin, N. (2015) Climate Change: Black Carbon and Atmospheric Feedbacks. Nature, 519, 167-168. https://doi.org/10.1038/519167a

[36] Hodnebrog, Ø., Myhre, G. and Samset, B.H. (2014) How Shorter Black Carbon Lifetime Alters Its Climate Effect. Nature Communications, 5, Article No. 5065. https://doi.org/10.1038/ncomms6065

[37] Endresen, Ø., Sørgård, E., Sundet, J.K., Dalsøren, S.B., Isaksen, I.S., Berglen, T.F. and Gravir, G. (2003) Emission from International Sea Transportation and Environmental Impact. Journal of Geophysical Research: Atmospheres, 108, 4650-4666. https://doi.org/10.1029/2002JD002898

[38] Lonati, G., Cernuschi, S. and Sidi, S. (2010) Air Quality Impact Assessment of At-Berth Ship Emissions: Case-Study for the Project of a New Freight Port. Science of the Total Environment, 409, 192-200. https://doi.org/10.1016/j.scitotenv.2010.08.029

[39] Miola, A. and Ciuffo, B. (2011) Estimating Air Emissions from Ships: Meta-Analysis of Modelling Approaches and Available Data Sources. Atmospheric Environment, 45, 2242-2251. https://doi.org/10.1016/j.atmosenv.2011.01.046

[40] Hulskotte, J.H.J. and Denier van der Gon, H.A.C. (2010) Fuel Consumption and Associated Emissions from Seagoing Ships at Berth Derived from an On-Board Survey. Atmospheric Environment, 44, 1229-1236. https://doi.org/10.1016/j.atmosenv.2009.10.018

[41] Cullinane, K. and Cullinane, S. (2013) Atmospheric Emissions from Shipping: The Need for Regulation and Approaches to Compliance. Transport Reviews, 33, 377-401. https://doi.org/10.1080/01441647.2013.806604

[42] Pey, J., Pérez, N., Cortés, J., Alastuey, A. and Querol, X. (2013) Chemical Fingerprint and Impact of Shipping Emissions over a Western Mediterranean Metropolis: Primary and Aged Contributions. Science of the Total Environment, 463-464, 497-507. https://doi.org/10.1016/j.scitotenv.2013.06.061

[43] Pérez, N., Pey, J., Reche, C., Cortés, J., Alastuey, A. and Querol, X. (2016) Impact of Harbour Emissions on Ambient PM10 and PM2.5 in Barcelona (Spain): Evidences of Secondary Aerosol Formation within the Urban Area. Science of the Total Environment, 571, 237-250. https://doi.org/10.1016/j.scitotenv.2016.07.025

[44] Cesari, D., Genga, A., Ielpo, P., Siciliano, M., Mascolo, G., Grasso, F.M. and Contini, D. (2014) Source Apportionment of PM2.5 in the Harbour-Industrial Area of Brindisi (Italy): Identification and Estimation of the Contribution of In-Port Ship Emissions. Science of the Total Environment, 497-498, 392-400. 
https://doi.org/10.1016/j.scitotenv.2014.08.007

[45] Donateo, A., Gregoris, E., Gambaro, A., Merico, E., Giua, R., Nocioni, A. and Contini, D. (2014) Contribution of Harbour Activities and Ship Traffic to PM2.5, Particle Number Concentrations and PAHs in a Port City of the Mediterranean Sea (Italy). Environmental Science \& Pollution Research, 21, 9415. https://doi.org/10.1007/s11356-014-2849-0

[46] Ledoux, F., Roche, C., Cazier, F., Beaugard, C. and Courcot, D. (2018) Influence of Ship Emissions on NOx, SO2, O3 and PM Concentrations in a North-Sea Harbor in France. Journal of Environmental Sciences, 71, 56-66. https://doi.org/10.1016/j.jes.2018.03.030

[47] Alver, F., Saraç, B.A. and Alver Şahin, Ü. (2018) Estimating of Shipping Emissions in the Samsun Port from 2010 to 2015. Atmospheric Pollution Research, 9, 822-828. https://doi.org/10.1016/j.apr.2018.02.003

[48] Nunes, R.A.O., Alvim-Ferraz, M.C.M., Martins, F.G. and Sousa, S.I.V. (2017) The Activity-Based Methodology to Assess Ship Emissions-A Review. Environmental Pollution, 231, 87-103. https://doi.org/10.1016/j.envpol.2017.07.099

[49] EEA European Environmental Agency (2016) European Aviation Environmental Report 2016.

https://ec.europa.eu/transport/sites/transport/files/european-aviation-environment al-report-2016-72dpi.pdf

[50] Kukkonen, J., Karl, M., Keuken, M.P., Denier van der Gon, H.A.C., Denby, B.R., Singh, V., Douros, J., Manders, A., Samaras, Z., Moussiopoulos, N., Jonkers, S., Aarnio, M., Karppinen, A., Kangas, L., Lützenkirchen, S., Petäjä, T. and Sokhi, R.S. (2016) Modelling the Dispersion of Particle Numbers in Five European Cities. Modelling the Dispersion of Particle Numbers in Five European Cities. Geoscientific Model Development, 9, 451-478. https://doi.org/10.5194/gmd-9-451-2016

[51] Healy, R.M., O’Connor, I.P., Hellebust, S., Allanic, A., Sodeau, J.R. and Wenger, J.C. (2009) Characterisation of Single Particles from In-Port Ship Emissions. Atmospheric Environment, 43, 6408-6414. https://doi.org/10.1016/j.atmosenv.2009.07.039

[52] González, Y. and Rodríguez, S. (2013) A Comparative Study on the Ultrafine Particle Episodes Induced by Vehicle Exhaust: A Crude Oil Refinery and Ship Emissions. Atmospheric Research, 120-121, 43-54. https://doi.org/10.1016/j.atmosres.2012.08.001

[53] Merico, E., Donateo, A., Gambaro, A., Cesari, D., Gregoris, E., Barbaro, E., Dinoi, A., Giovanelli, G., Masieri, S. and Contini, D. (2016) Influence of In-Port Ships Emissions to Gaseous Atmospheric Pollutants and to Particulate Matter of Different Sizes in a Mediterranean Harbour in Italy. Atmospheric Environment, 139, 1-10. https://doi.org/10.1016/j.atmosenv.2016.05.024

[54] Kopanakis, I., Chatoutsidou, S.E., Glytsos, T. and Lazaridis, M. (2018) Impact from Local Sources and Variability of Fine Particle Number Concentration in a Coastal Sub-Urban Site. Atmospheric Research, 213, 136-148.

https://doi.org/10.1016/j.atmosres.2018.06.002

[55] Moldanová, J., Fridell, E., Winnes, H., Holmin-Fridell, S., Boman, J., Jedynska, A., Tishkova, V., Demidjian, B., Joulie, S., Bladt, H., Ivleva, N.P. and Niessner, R. (2013) Physical and Chemical Characterisation of PM Emissions from Two Ships Operating in European Emission Control Areas. Atmospheric Measurement Techniques Discussions, 6, 3931-3982. https://doi.org/10.5194/amtd-6-3931-2013 
[56] González, Y., Rodríguez, S., Guerra García, J.C., Trujillo, J.L. and García, R. (2011) Ultrafine Particles Pollution in Urban Coastal Air Due to Ship Emissions. Atmospheric Environment, 45, 4907-4914. https://doi.org/10.1016/j.atmosenv.2011.06.002

[57] Merico, E., Gambaro, A., Argiriou, A., Alebic-Juretic, A., Barbaro, E., Cesari, D., Chasapidis, L., Dimopoulos, S., Dinoi, A., Donateo, A., Giannaros, C., Gregoris, E., Karagiannidis, A., Konstandopoulos, A.G., Ivošević, T., Liora, N., Melas, D., Mifka, B., Orlić, I., Poupkou, A., Sarovic, K., Tsakis, A., Giua, R., Pastore, T., Nocioni, A. and Contini, D. (2017) Atmospheric Impact of Ship Traffic in Four Adriatic-Ionian Port-Cities: Comparison and Harmonization of Different Approaches. Transportation Research Part D, 50, 431-445. https://doi.org/10.1016/j.trd.2016.11.016

[58] Lyu, X.P., Guo, H., Cheng, H.R. and Wang, D.W. (2018) New Particle Formation and Growth at a Suburban Site and a Background Site in Hong Kong. Chemosphere, 193, 664-674. https://doi.org/10.1016/j.chemosphere.2017.11.060

[59] Hofman, J., Staelens, J., Cordell, R., Stroobants, C., Zikova, N., Hama, S., Wyche, K., Kos, G., Van Der Zee, S., Smallbone, K., Weijers, E., Monks, P. and Roekens, E. (2016) Ultrafine Particles in Four European Urban Environments: Results from a New Continuous Long-Term Monitoring Network. Atmospheric Environment, 136, 68-81. https://doi.org/10.1016/j.atmosenv.2016.04.010

[60] Hama, S.M.L., Cordell, R.L. and Monks, P.S. (2017) Quantifying Primary and Secondary Source Contributions to Ultrafine Particles in the UK Urban Background. Atmospheric Environment, 166, 62-78. https://doi.org/10.1016/j.atmosenv.2017.07.013

[61] Pushpawela, B., Jayaratne, R. and Morawska, L. (2018) Temporal Distribution and Other Characteristics of New Particle Formation Events in an Urban Environment. Environmental Pollution, 233, 552-560. https://doi.org/10.1016/j.envpol.2017.10.102

[62] Babu, S.S., Kompalli, S.K. and Moorthy, K.K. (2016) Aerosol Number Size Distributions over a Coastal Semi Urban Location: Seasonal Changes and Ultrafine Particle Bursts. Science of the Total Environment, 563-564, 351-365. https://doi.org/10.1016/j.scitotenv.2016.03.246

[63] Liu, S., Hu, M., Wu, Z., Wehner, B., Wiedensohler, A. and Cheng, Y. (2008) Aerosol Number Size Distribution and New Particle Formation at a Rural/Coastal Site in Pearl River Delta (PRD) of China. Atmospheric Environment, 42, 6275-6283. https://doi.org/10.1016/j.atmosenv.2008.01.063

[64] Rodríguez, S., Cuevas, E., González, Y., Ramos, R., Romero, P.M., Pérez, N., Querol, X. and Alastuey, A. (2018) Influence of Sea Breeze Circulation and Road Traffic Emissions on the Relationship between Particle Number, Black Carbon, PM1, PM2.5 and PM2.5-10 Concentrations in a Coastal City. Atmospheric Environment, 42, 6523-6534. https://doi.org/10.1016/j.atmosenv.2008.04.022

[65] Hama, S.M.L., Cordell, R.L., Kos, G.P.A., Weijers, E.P. and Monks, P.S. (2017) Sub-Micron Particle Number Size Distribution Characteristics at Two Urban Locations in Leicester. Atmospheric Research, 194, 1-16. https://doi.org/10.1016/j.atmosres.2017.04.021

[66] Huang, C., Tao, S., Lou, S., Hu, Q., Wang, H., Wang, Q, Li, L, Wang, H., Liu, J., Quan, Y. and Zhou, L. (2017) Evaluation of Emission Factors for Light-Duty Gasoline Vehicles Based on Chassis Dynamometer and Tunnel Studies in Shanghai, China. Atmospheric Environment, 169, 193-203.

https://doi.org/10.1016/j.atmosenv.2017.09.020 
[67] Mordas, G., Plauškaite, K., Prokopčiuk, N., Dudoitis, V., Bozzetti, C. and Ulevicius, V. (2016) Observation of New Particle Formation on Curonian Spit Located between Continental Europe and Scandinavia. Journal of Aerosol Science, 97, 38-55. https://doi.org/10.1016/j.jaerosci.2016.03.002

[68] Russo, A., Lind, P.G., Raischel, F., Trigo, R. and Mendes, M. (2014) Neural Network Forecast of Daily Pollution Concentration Using Optimal Meteorological Data at Synoptic and Local Scales. Atmospheric Pollution Research, 6, 540-549. https://doi.org/10.5094/APR.2015.060

[69] Russo, A., Trigo, R.M., Martins, H. and Mendes, M.T. (2014b) $\mathrm{NO}_{2}, \mathrm{PM}_{10}$ and $\mathrm{O}_{3}$ Urban Concentrations and Its Association with Circulation Weather Types in Portugal. Atmospheric Environment, 89, 768-785.

https://doi.org/10.1016/j.atmosenv.2014.02.010

[70] Monjardino, J., Barros, N., Ferreira, F., Tente, H., Fontes, T., Pereira, P. and Manso, C. (2018) Improving Air Quality in Lisbon: Modelling Emission Abatement Scenarios. 1 st IFAC Workshop on Integrated Assessment Modelling for Environmental Systems, Brescia, 10-11 May 2018, University of Brescia, Vol. 51, 61-66. https://doi.org/10.1016/j.ifacol.2018.06.211

[71] FCT-NOVA (2017) Inventário de Emissões Atmosféricas da Região de Lisboa e Vale do Tejo 2011-2014. CCDR LVT, Maio. http://www.ccdr-lvt.pt/files

[72] Lopes, M., Russo, A., Monjardino, J., Gouveia, C. and Ferreira, F. (2019) Monitoring of Ultrafine Particles in the Surrounding Urban Area of a Civilian Airport. Atmospheric Pollution Research. https://doi.org/10.1016/j.apr.2019.04.002

[73] Ferreira, F., Gomes, P., Tente, H., Carvalho, A., Pereira, P. and Monjardino, J. (2015) Air Quality Improvements Following Implementation of Lisbon's Low Emission Zone. Atmospheric Environment, 12, 2373-2381. https://doi.org/10.1016/j.atmosenv.2015.09.064

[74] Russo, A. and Soares, A.O. (2013) Hybrid Model for Urban Air Pollution Forecasting: A Stochastic Spatio-Temporal Approach. Mathematical Geosciences, 46, 75-93. https://doi.org/10.1007/s11004-013-9483-0

[75] P-Trak (2013) P-Trak Ultrafine Particle Couter Model 8525. Operation and Service Manual. (TrakproTM Data Analysis Software Enclosed) P/N 19803880, Revision M July 2013.

[76] Kumar, P., Robins, A., Vardoulakis, S. and Quincey, P. (2011) Technical Challenges in Tackling Regulatory Concerns for Urban Atmospheric Nanoparticles. Particuology, 9, 566-571. https://doi.org/10.1016/j.partic.2011.06.002 